Mr. Edin HALILOVIĆ

JU Osnovna škola "Gnojnica” Lukavac

E-mail: edinhalilovic1978@yahoo.com

Stručni rad/Professional article

UDK/UDC: 94(497.6)"19/20" (082)

\title{
75. GODIŠNJICA PRVOG ZASJEDANJA ZAVNOBIH-a: POVIJESNA UTEMELJENOST OBNOVLJENE DRŽAVNOSTI BOSNE I HERCEGOVINE U 20. I 21. STOLJEĆU, Zbornik radova, Posebna izdanja, knjiga CLXXIX, Odjeljenje društvenih nauka, knjiga 11/1, Odjeljenje humanističkih nauka, knjiga 46/1, Akademija nauka i umjetnosti Bosne i Hercegovine, Sarajevo 2019, 574 str.
}

Povodom 75 godina od održavanja Prvog zasjedanja ZAVNOBiH-a Odjeljenje društvenih i Odjeljenje humanističkih nauka Akademije nauka i umjetnosti Bosne i Hercegovine inicirali su pripremu i održavanje Međunarodne naučne konferencije: 75. godišnjica

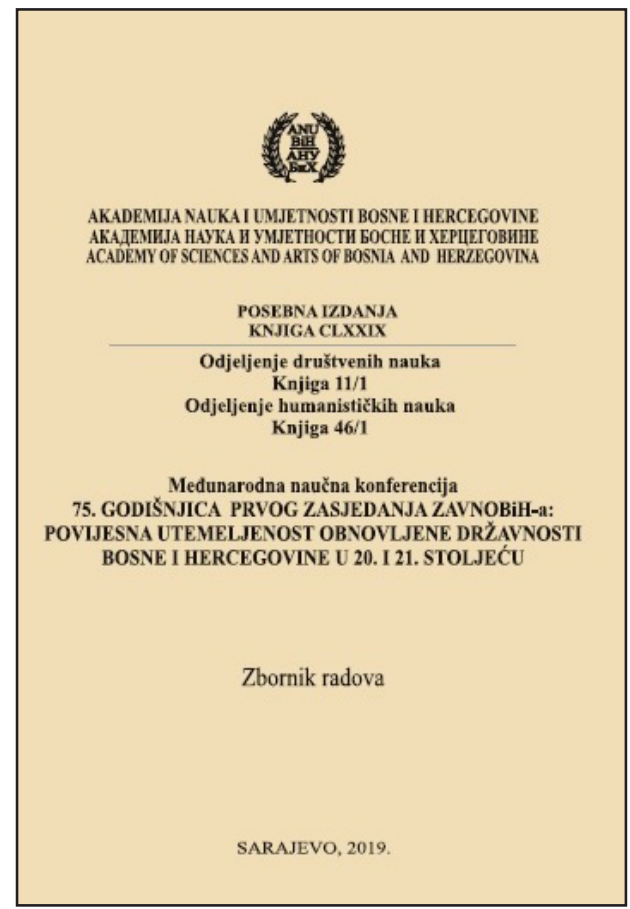

ZAVNOBiH-a: Povijesna utemeljenost obnovljene državnosti Bosne $i$ Hercegovine u 20. $i$ 21. stoljeću. U višemjesečnom zajedničkom radu odbora pokrenute su aktivnosti koje su omogućile prijavu većeg broja naučnih radnika za učešće na naučnoj konferenciji. Tako je za Zbornik radova i izlaganje na Konferenciji odabrano 25 radova.

Zbornik radova na 574 stranice daje prikaz 25 radova u dvije tematske cjeline. Veliki broj bibliografskih jedinica doprinose kvaliteti radova. Svi radovi su rezultat znanstvenih istraživanja autora iz zemlje i inozemnstva uz korištenje relevantne metodologije s obzirom na vrstu rada.

Tematska cjelina Značaj ZAVNOBiH-a u historiji Bosne $i$ Hercegovine obuhvata 14 radova koji obrađuju problematiku vezanu za obnovu i razvoj državnosti Bosne i Hercegovine u drugoj polovini 20. stoljeća. Političko-ustavna organizacija bosanskohercegovačkog društva, utemeljena odlukama Prvog (1943), Drugog (1944) i Trećeg (1945) 
zasjedanja ZAVNOBiH-a, postala je historijski pronađen politički oblik organizacije multietničkog i multikulturnog društva koje u viševjekovnom trajanju egzistira $u$ Bosni i Hercegovini. Bit njene državnosti je ravnopravnost građana $\mathrm{i}$ istovremeno ravnopravnost naroda koji žive u Bosni i Hercegovini.

Na temelju objavljene i neobjavljene arhivske građe i relevantne literature, data je analiza koja prikazuje velikodržavne politike podjele Bosne i Hercegovine u periodu između dva svjetska rata i u Drugom svjetskom ratu, kao i historijski značaj odluka ZAVNOBiH-a kojima su negirane velikodržavne politike. Ukazano je i na činjenicu da ZAVNOBiH predstavlja historijski odgovor antifašističkih snaga na velikosrpsku i velikohrvatsku politiku teritorijalne podjele i uništenja Bosne $\mathrm{i}$ Hercegovine. Promatranje uloge historijskog mjesta, kao simboliziranog prostora $u$ obilježavanju značajnih historijskih događaja, omogućava sagledavanje promjena vrijednosnih okvira koji su oblikovali dominantne javne percepcije. Odnos prema razvoju državnosti Bosne i Hercegovine, praćen na primjerima Bihaća, MrkonjićGrada i Jajca, prikazuje utjecaj društveno-političkih događanja na dinamiku sjećanja i valorizaciju tekovina antifašizma, prije i nakon disolucije Jugoslavije.

U vremenu poslije Drugog svjetskog rata državnost Bosne i Hercegovine se razvijala u društveno-historijskom kontekstu izvođenja ustavno-pravnih i socijalnih reformi. Jedan broj autora referata obrađuje socijalni, ekonomski, kulturni i politički razvoj Bosne i Hercegovine od 1945. do 1990. godine, kada Bosna i Hercegovina postiže civilizacijska dostignuća u svim oblastima društvenog razvoja. U okviru ukupnog ekonomskog, kulturnog i socijalnog razvoja Socijalističke republike Bosne i Hercegovine izrasla je moderna i snažna državna vlast Bosne i Hercegovine. Kao jedna od glavnih pretpostavki razvoja državnosti Bosne i Hercegovine od 1960. do 1990. godine javlja se političko jedinstvo republičkog rukovodstva u vođenju državnog razvoja Bosne i Hercegovine.

Dostignuti nivo razvoja državnosti Bosne i Hercegovine omogućio je da se potkraj 90-ih godina 20. stoljeća mirno izvede politička pluralizacija bosanskohercegovačkog društva i uvede višepartijski sistem. U prvoj godini rada višestranačke Skupštine Republike Bosne i Hercegovine, tokom 1991. i početkom 1992. godine, Bosna i Hercegovina je voljom većine svojih građana na referendumu o suverenom i nezavisnom statusu Bosne i Hercegovine 29. februara i 1. marta 1992. godine dobila svoj novi državno-pravni status. Na temelju volje građana o suverenom i nezavisnom statusu države Bosne i Hercegovine uslijedilo je međunarodno priznanje u aprilu mjesecu 1992. godine od zemalja Evropske zajednice, Sjedinjenih Američkih Država i velikog broja zemalja svijeta. Potom je uslijedio 22. maja 1992. godine prijem Bosne i Hercegovine u članstvo Organizacije Ujedinjenih nacija.

U drugoj tematskoj cjelini Percepcija ZAVNOBiH-a nakon 1992. godine autori su elaborirali više tema koje se odnose na aspekte osporavanja ZAVNOBiH-a, zatim posljedice agresije na Bosnu i Hercegovinu u vremenu rata 1992-1995, kao i na političko-pravna ograničenja državno-pravnog i političkog razvoja Bosne i 
Hercegovine koja proističu iz odredbi Dejtonskog ustava za Bosnu i Hercegovinu. Pažnju privlači razmatranje normativnih rješenja i, posebno, primjene dejtonskog ustavnog poretka po kriterijima vrijednosti uspostavljenih ZAVNOBiH-om. To razmatranje dovodi do zaključka da je neuvažavanje ovih vrijednosti u kreiranju dejtonskog ustavnog poretka i u njegovoj realizaciji ključni razlog njegovih slabosti, posebno nedemokratičnosti i neučinkovitosti.

Nezaobilazna je i medijska prezentacija ZAVNOBiH-a koja uglavnom ima dvojako i politički koordinirano izvještavanje o temi bosanskohercegovačke državnosti. Rezultat toga je oštro podijeljen javni diskurs, općenito i o bosanskohercegovačkoj državnosti, ali i o ZAVNOBiH-u. Jedan broj autora ukazuje na historijske prijelomnice, ključne za izgradnju identiteta bosanskohercegovačke posebnosti i paradigme jedinstva $\mathrm{u}$ različitosti. Teorijska elaboracija historijskih spoznaja o obnovi i razvoju državnosti Bosne i Hercegovine u 20. i 21. stoljeću omogućila je i nova istraživanja koja će subjektima društvenog odlučivanja pomoći u oblikovanju društvenih reformi tokom procesa integracije Bosne i Hercegovine u Evropsku uniju na početku 21. stoljeća. U tom kontekstu, historijski temelji i osnove za sve reforme u društvenom razvoju Bosne i Hercegovine postoje u odlukama Prvog zasjedanja ZAVNOBiH-a. Rezolucijom Prvog zasjedanja ZAVNOBiH-a utemeljen je koncept državnosti multietničkog i multikulturnog društva kakvo je bosanskohercegovačko društvo.

$\mathrm{Na}$ naučnom skupu u povodu 75-godišnjice ZAVNOBiH-a učestvovali su istraživači i stručnjaci različitih profila društvenih nauka s namjerom i željom da kroz svoja razmišljanja i raspravu pokušaju doprinijeti možda ne toliko nekim novim saznanjima o prošlosti koliko sadašnjim i budućim povoljnijim društvenim procesima u razvoju ove zemlje i njenog stanovništva. Navedeni Zbornik radova će svakako biti od velike koristi budućim generacijama historičara, ali i širem kruga čitalaca koji žele da znaju ne samo šta je sada već i kako je ranije bilo, da bi, iz ugla historijskih činjenica, mogli bolje shvatiti vrijeme u kome sada žive. 